\title{
THESES
}

\section{PREVALENCE STUDY OF NEUROLOGIC MANIFESTATIONS IN HTLV-I POSITIVE BLOOD DONORS (ABSTRACT)*.THESIS. NITEROI, 1999.}

\section{ANA CLÁUDIA CELESTINO BEZERRA LEITE**}

The human T-lymphotropic virus type I (HTLV-I) is the etiologic agent of tropical spastic paraparesis / HTLV-I associated myelopathy (TSP/HAM), adult T cell leukemia/lymphoma (ATLL) as well as of other immunomediated systemic diseases. Contrary to other pathogenic viruses to man HTLV-I apparently causes diseases in the minority of the infected population. The real prevalence of HTLV-I neurologic manifestations is still reason for debate in the literature with percentages ranging from $0.07 \%$ to $2.6 \%$. The relation between an increased risk for development of disease and other contributing cofactors is also speculated. The continuous prospective observation of infected individuals has suggested to us that the prevalence of neurological manifestations might be higher than what is presently assumed. In order to evaluate the prevalence of signs and symptoms of neurological involvement in a population of blood donors from the largest blood bank from the city of Rio de Janeiro, Brazil (HEMORIO) and also the possible correlation of epidemiological variables which could possibly contribute to a higher risk of development of neurological disease we designed the present study.

Between May 1995 to December 1997, 392 blood donors from HEMORIO were selected by a cross sectional study. Fifty percent of these individuals were HTLV-I positive. For the prevalence study, neurologically impaired HTLV-I positive individuals were considered cases and HTLV-I positive individuals with a normal neurological examination, controls. Cases were classified in symptomatics and asymptomatics, and according to the topographic diagnosis (involvement of the central [CNS], peripheral [PNS] nervous system or muscle). Patients underwent specific laboratory investigations. The method of case-control study was employed for the evaluation of risk factors for the presence of neurological disease. For this part of the study HTLV-I positive patients were classified as cases, and seronegative asymptomatic individuals as controls.

Neurological disease was found in $71(36.2 \%)$ out of 196 seropositive individuals. Of these, $34(48 \%)$ individuals had involvement of the CNS (11 [32.3\%] TSP/HAM cases); 33 (46\%) patients with involvement of PNS (18 [54.5\%] cases of polyneuropathy) and 4 (6\%) patients with muscular disease (one case of polymyositis). Previous use of intravenous drugs (OR 9.9 and CI95\% 1.9-68.5), family history of either HTLV-I infection or HTLV-I associated disease (OR 7.5 and CI95\% 3.1-18.8), risky sexual behavior (OR 6.9 and CI95\% 2.5-20.4), hemotransfusion in the past (OR 6.7 and CI95\% 2.7-17), and a history of either HTLV-I infection or HTLV-I associated diseases (OR 9.9 and CI95\% 1.8-11.6) were significantly associated to the presence of neurological disease among HTLV-I seropositives. Hypergammaglobulinemia and ophthalmologic abnormalities were also significantly associated to the presence of those neurologic disorders.

Our data suggest that the exposition to HTLV-I was significantly associated to the development of neurological disease in a higher proportion than what has been published so far in the literature. The involvement of PNS and muscle was more expressive than the isolated CNS involvement. Some variables and laboratory abnormalities can act as cofactors that could predispose to development of neurological disease among seropositive individuals. This implies in the necessity of a more detailed epidemiological inquiry among candidates for blood donation. We speculate that a detailed neurological examination of this population allowed a higher accuracy in the diagnosis of HTLV-I associated neurological manifestations.

\section{blood donors .}

KEY WORDS: HTLV-I associated myelopathy, tropical spastic paraparesis, peripheral neuropathy,

\footnotetext{
*Estudo da prevalência das manifestações neurológicas em doadores de sangue HTLV-I positivos (Resumo) Tese de Doutorado, Faculdade de Medicina da Universidade Federal Fluminense (Área: Neurologia). Orientadores: Abelardo de Queiroz-Campos Araújo, Gulnar Mendonça, Osvaldo José Moreira Nascimento.

**Address: Rua Conde Bonfim 211 / 702, 20520-020 Rio de Janeiro RJ, Brasil. E-mail: analeite@mandic.com.br
} 


\section{COMPUTED TOMOGRAPHY AND ELECTROENCEPHALOGRAPHY IN EVALUATION OF CHILDREN WITH MOTOR AND LANGUAGE DISORDERS (ABSTRACT)*. THESIS. MARÍLIA, 1999.}

\section{EDWARD ROBERTO TONHOLO SILVA **}

In order to study the utility of computed tomography (CT) scan of the head and electroencephalogram (EEG) in the evaluation of children with neuropsychomotor developmental delay as well as to evaluate possible correlations between these two testing modalities, we reviewed the head CT and EEG findings in 111 children with motor and language disorders. The children were of both sexes and were divided into three groups by age: 0-12 months, 13-48 months and greater than 48 months.

Motor and language skills of these children were evaluated with respect to performance scales derived from specialized literature. CT scans were first categorized as either normal or abnormal and abnormal scans were further divided into: 1) those showing peripheral (cortical) atrophy; 2) those showing central or periventricular atrophy; 3) those with malformations; and 4) those showing disorders of cerebral blood vessels. EEG findings were first categorized as either normal or abnormal and abnormal studies were categorized as showing: 1) paroxysmal patterns; or 2) rhythm abnormalities.

Sixty per cent of the children had normal head CT scans. This finding was independent of age and sex. Peripheral (cortical) abnormality was the most common morphological finding, and was present in about $17 \%$ of the children of both sexes and was more prevalent in the younger age groups (under 48 months). Vascular abnormality predominated in the older age group (greater than 48 months).

Overall, about $50 \%$ of the children had abnormal EEG exams independent of their sex; however, normal exams predominated in the first year of life. Paroxysmal patterns occurred in all ages but prevailed in females during the first year of life.

With respect to behavior, 77\% of children had global delay, most often in females in the first year of life. Isolated motor delay predominated in both sexes in the first year of life. Language delay predominated in male children greater than 48 months, a statistically significant finding.

Results of CT-scan and EEG were normal in $32 \%$ of children, mainly in boys and in children older than 48 months. Abnormal CT and EEG exams predominated in children older than 48 months independent of sex.

CT scan of the head was shown to have a limited diagnostic value in children with developmental disturbance. Similarly, EEG showed functional alterations in these children but without value of localizing the developmental abnormality. CT and EEG abnormalities were more prevalent in girls while normal exams were more common in boys confirming that, in terms of plasticity, girls have less potential than boys.

\section{disorder, children.}

KEY-WORDS: computed tomography scan, electroencephalography, motor disorder, language

*Tomografia e eletrencefalografia no diagnóstico de distúrbios motor e de linguagem em crianças (Resumo). Tese de Mestrado, Faculdade de Medicina da Universidade de Marília (Área: Morfologia). Orientador: Raymundo Manno Vieira.

**Address: Rua Júlio Mesquita 295, 17515-230 Marília SP, Brasil. E-mail: angbeto@ unimedmarilia.com.br

\section{CLINICAL AND ELECTROENCEPHALOGRAPHICAL CHARACTERIZATION OF TYPICAL ABSENCE SEIZURES (ABSTRACT)*. THESIS. SÃO PAULO, 1999.}

\section{LAURA MARIA DE FIGUEIREDO FERREIRA GUILHOTO**}

We recorded by video-EEG 455 typical absences in 43 patients aged 17 months to 53 years. Typical absence was defined as the Seizure Classification of the International League Against Epilepsy (ILAE) (1981) as follows: "sudden onset, interruption of activities, blank stare and possible upward rotation of the eyes". Syndromic diagnosis was possible in $60.46 \%$ of the cases according to the criteria of the Commission on Classification and Terminology of the ILAE (1989) and in 67.44\% using the proposal of Panayiotopoulos (1997). In the remaining patients there was a wide spectrum of electro-clinical presentations that could not fit the described syndromic approach. In this series there were specific ictal syndromic characteristics in absence seizures as proposed by Panayiotopoulos et al. (1989).

Patients with childhood absence epilepsy $(n=10)$ presented more severe ictal impairment of consciousness than the ones with juvenile absence epilepsy $(n=14)$. Interictal occipital intermittent rhythmic delta activity, present in $90 \%$ of the cases with childhood absence epilepsy, was not recorded in the juvenile form. 
Patients with myoclonic absence epilepsy $(n=3)$ had pyknoleptic absences with severe alteration of consciousness accompanied by massive rhythmic myoclonic jerks of upper limbs and one patient with juvenile myoclonic epilepsy had absence seizures of short duration (mean 3.2sec) associated with irregular spike-wave complexes.

Finally, one patient with eyelid myoclonia with absences had seizures of short duration (mean 2.94sec) evoked by eye closure and intermittent photostimulation.

Ten patients older than 20 years had more often tonic-clonic associated seizures, difficulty in seizure control, subtle impairment of consciousness and irregular spike-wave complexes during the ictus, when compared to the ones younger than ten years. In four of these patients ictal electroencephalographical 10-20 Hz activity was associated.

Patients with severe ictal impairment of consciousness more often presented pyknolepsy $(\mathrm{p}=0.005)$ and earlier seizure onset $(\mathrm{p}=0.028)$ than those with partial impairment. Patients with regular electrographical patterns had more frequent pyknolepsy $(\mathrm{p}=0.028)$, earlier seizure onset $(\mathrm{p}=0.026)$, automatisms $(\mathrm{p}=0.047)$ and less often tonic-clonic seizures $(\mathrm{p}=0.011)$ than those with irregular spike-wave complexes.

Although there were a few photosensitive patients $(n=3)$ in this series, seizure outcome was not correlated with photosensitivity in this group.

Neuropsychological evaluation of these patients showed a tendency to more frequent attention impairment than cognitive disorders.

\section{classsification.}

KEY WORDS: typical absences, idiopathic generalized epilepsy, electroencephalography,

*Caracterização clínica e eletrencefalográfica de crises de ausência típica (Resumo). Tese de Doutorado, Faculdade de Medicina de da Universidade de São Paulo (Área Neurologia). Orientadora: Elza Márcia Targas Yacubian.

**Address: Rua Bom Jesus 864, 03344-000 São Paulo SP, Brasil.

\section{SYMPTOMS OF DEPRESSION AND ANXIETY, AND SCREENING FOR MENTAL DISORDER IN MIGRAINOUS PATIENTS (ABSTRACT)*. DISSERTATION . PORTOALEGRE, 1999.}

\section{FERNANDOKOWACS**}

Introduction. Many publications describe the existence of association between migraine and depression and anxiety disorders. The purpose of this study was the assessment of variability and frequency of symptoms of depression, anxiety, and non-specific psychiatric disorder among patients with migraine, compared to normal subjects and to individuals with a non-neurological chronic disease.

Method. A controlled cross-sectional study was carried out in which 178 individuals (migraine 51; psoriasis 35; normal 92) were submitted to the Montgomery-Åsberg Depression Rating Scale (symptoms of depression), State-Trait Anxiety Inventory-Trait Form (symptoms of anxiety) and Self-report Questionnaire (screening for mental disorder). The subjects with migraine and psoriasis were from the Outpatient Clinics of Headache and of Dermatology, and the normal volunteers were persons who accompany outpatients in the same hospital (Hospital de Clínicas de Porto Alegre). Scores were analyzed by MANOVA, with control to gender, age, and educational level, by association analysis, and by logistic regression.

Results. Scores of all instruments were higher in migrainous group, but the univariate analysis of association (using cutoffs) showed significance only for suspicion of mental disorder (SRQ). By logistic regression, variables with strongest association to migraine were gender, education, and SRQ in a decreasing order.

\section{KEYWORDS: migraine, depression, anxiety, mental disorder.}

*Avaliação de sintomas depressivos, de ansiedade e de transtorno mental inespecífico em pacientes portadores de migrânea (Resumo). Dissertação de Mestrado, Faculdade de Medicina da Universidade Federal do Rio Grande do Sul (Área: Clínica Médica). Orientadora: Márcia Lorena Fagundes Chaves.

**Address: Avenida João Obino 285, 90470-150 Porto Alegre RS, Brasil. E-mail: f kowacs@ yahoo.com 
THE COGNITIVE POTENTIALS IN KIDNEY FAILURE BEFORE AND AFTER HEMODIALYSIS (ABSTRACT)*. THESIS. NITEROI, 1999.

\section{GLAUCIO MENDES FRANCO**}

The main objective of this study was to evaluate the possible alterations of the endogenous potentials by the kidney failure.

Method: Twenty-five patients were studied before and after hemodyalisis. The results obtained were compared with data collected from 25 healthy volunteers (control group).

Results: The comparative study between the control group and the patients revealed, both in $\mathrm{Cz}$ and $\mathrm{Fz}$, increased latencies of $\mathrm{N} 2$ and $\mathrm{P} 3$. The values obtained after dyalisis indicated some improvement.

Conclusion: It was demonstrated that when we compare a group of healthy volunteers and a group of patients with kidney failure, all latencies were systematically increased in the group of patients. The same variables remained significantly increased after the hemodyalisis but at lower levels, what was probably related with some therapeutic effect of the dialysis. The data evaluated suggest that the latest phases of the cognitive process were more intensely disturbed.

\section{KEY WORDS: cognitive potentials, kidney failure, hemodyalisis.}

* O potencial evocado $\mathrm{P} 300$ em pacientes renais crônicos antes e depois da hemodiálise (Resumo). Tese de Doutorado, Universidade Federal Fluminense. Orientador: Pedro Ferreira Moreira Filho.

**Address: Rua Oscar Vidal 245 / 1502, 36016-290 Juiz de Fora MG, Brasil.

THESES é seção de Arquivos de Neuro-Psiquiatria que divulga os resumos em inglês de teses defendidas e aprovadas. O assunto da tese deve estar relacionado a aspectos clínicos ou experimentais de interesse em neurologia e ciências a ela afins.

Para publicação, o Autor deve encaminhar ao Editor: abstract da tese, acompanhado do título em inglês e em português; key words; disquete com a reprodução desses dados.

Adicionalmente, o Autor deve informar: a natureza da tese (Dissertação/Tese de Mestrado, Tese de Doutorado, Tese de Livre-Docência - como exemplos); nome da instituição na qual foi defendida e respectiva área de concentração; nome do Orientador, quando for o caso; endereço para correspondência. 